\title{
Sex determination of cattle meat by polymerase chain reaction amplification of the amelogenin (AMELX/ AMELY) gene
}

\author{
P. Gokulakrishnan, R. R. Kumar, B. D. Sharma, S. K. Mendiratta, D. Sharma ${ }^{1}$, O. P. Malav \\ Division of Livestock Products Technology, \\ Indian Veterinary Research Institute, Izatnagar-243 122, Uttar Pradesh, India \\ 1. Genome Mapping Laboratory, Central Avian Research Institute, Izatnagar-243 122, Uttar Pradesh, India. \\ Corresponding author: P. Gokulakrishnan, e-mail:vetgokul@gmail.com \\ Received:11-02-2012, Accepted: 25-03-2012, Published Online: 10-06-2012 \\ doi: $10.5455 /$ vetworld.2012.526-529
}

\begin{abstract}
Aim: The objective of this study was to develop a simplified, efficient, and accurate protocol for sexing of cattle meat based on the amelogenin (AMELX/AMELY) gene using PCR technique which is superior to earlier work in terms of band patterns. Materials and Methods: Based on the amelogenin gene located on the conservation region of $\mathrm{X}$ and $\mathrm{Y}$ chromosomes, a pair of primers was designed and the system of PCR was established to amplify a 241-bp fragment from the X chromosome in female cattle, and a 241-bp fragment from X chromosome and 178-bp fragment from the Y chromosome in male cattle, respectively. The accuracy and specificity of the primers was assessed using DNA template extracted from cattle meat samples of known sex. The protocol was subjected to a blind test showed $100 \%$ concordance, proving its accuracy and reliability.

Results: PCR products of cattle meat samples after electrophoresis showed two bands (241, 178-bp) for tissue from male while female tissue resulted in only one (241-bp) band.

Conclusions: Our findings show that the PCR assay based on the amelogenin gene is reliable for sex determination in cattle meat.

Keywords: Amelogenin gene, Cattle meat, PCR, Sex determination
\end{abstract}

To cite this article: Gokulakrishnan P, Kumar RR, Sharma BD, Mendiratta SK, Sharma D, Malav OP (2012) Sex determination of cattle meat by polymerase chain reaction amplification of the amelogenin (AMELX/AMELY) gene, Vet World, 5(9): 526-529, doi: 10.5455/vetworld.2012.526-529

\section{I ntroduction}

Determination of sex origin of cattle meat has been always of public interest in country like India where slaughter of cow (female cattle) is banned because of religious beliefs and laws thereby. The economic aspect allied with such discriminatory slaughter policy also gets support as male beef is designated to be of higher quality than cow meat and therefore yield higher prices [1] particularly in European countries. To implement the regulations pertaining to such issues and to assure consumers of accurate labeling meat analysts need to have reliable, authentic and simple method for determining the sex of cattle meat.

To date, a range of different methodologies have been developed for determining the sex of meat, mainly based on detecting either hormone or DNA [1]. In general terms, hormone-based methods include immunochemical determination using ELISA [2], and chromatographic techniques with mass-spectrometric detection, such as high performance liquid chromatography-mass spectrometry/mass spectrometry (HPLC
-MS/MS) [3] and gas chromatography-mass spectrometry (GC-MS) [4]. Most of the methods proved to be highly specific and sensitive, but were not performed on a regular basis for meat sexing due to the technical limitations or the expensive equipments required.

Over the last few decades, DNA-based techniques, especially polymerase chain reaction (PCR)-based methods for meat sexing have received particular attention, and have proved to be reliable, sensitive, and fast [5,6]. DNA regions that differ between male and female individuals are essential features in PCR sex determination. In general, these methodologies were developed mainly based on amelogenin gene (AMELX and AMELY) [7-9], zinc finger gene (ZFX and ZFY) [10-13] and the sex determination region of the Y chromosomal gene (SRY) [14-16]. Alternatively, the bovine-specific repetitive sequence BRY-1 [17] and the single copy sequence BOV97 M [18] are also used in the analysis for the sexing of cattle. More recently, based on real time PCR, both SYBR Green [19] and TaqMan [20] technology for bovine sex 


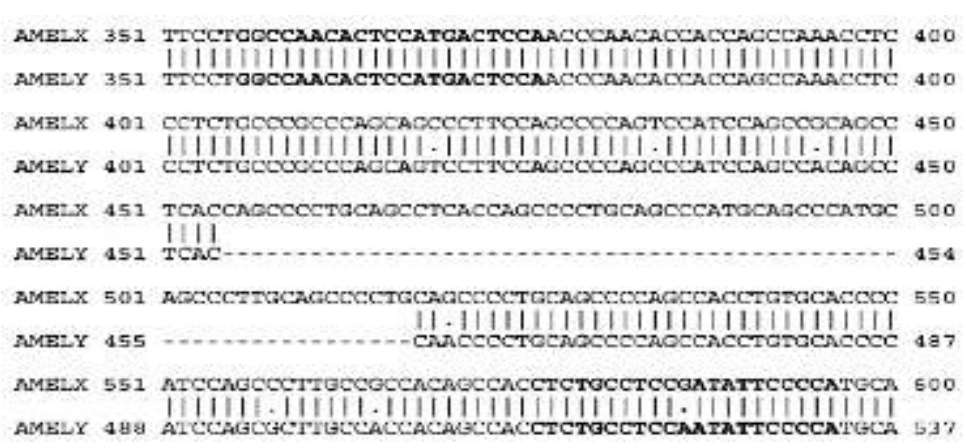

Figure-1. Alignment of the AMELX and AMELY gene sequences (GenBank Accession no. M63499.1 and M63500.1). The primers AML-1F and $A M L-1 R$ are indicated by bold letters. Dashes indicates gaps in alignment.

determination have been reported.

Amelogenin has been targeted by number of workers, where samples from male show two bands and female show only one band. Ennis and Gallagher [7] reported the primer pairs which yielded 280 and $217 \mathrm{bp}$, whereas the primer pairs, suggested by Chen et al [8] resulted in amplified product of 417 and 340bp, in case of cattle. The purpose of the present work was to develop a protocol for sexing of cattle meat based on the amelogenin gene (AMELX/AMELY) using PCR technique which is superior to earlier work in terms of band patterns.

\section{Materials and methods}

Sample selection and DNA extraction: A total of 16 muscle tissue samples of cattle ( 8 male and 8 female) were collected from local market of Kerala and West Bengal, India. The collected samples were transported to the laboratory under refrigeration, and were stored frozen at $-20^{\circ} \mathrm{C}$ prior to analysis. Genomic DNA was extracted from the samples using the DNeasy ${ }^{\circledR}$ blood and tissue kit (QIAGEN, Germany) according to the manufacturer's instructions. Subsequently, the quality of genomic DNA was assessed by agarose gel electrophoresis using $0.8 \%$ agarose gel (AMRESCO, USA) stained with ethidium bromide. The purity and concentration of DNA was estimated spectrophotometrically using Nanodrop ${ }^{\circledR}$ ND-1000 spectrophotometer (Thermo Scientific) at 260 and $280 \mathrm{~nm}$. The DNA sample showing the OD 260:280 nm value of 1.70-1.90 was considered as good quality.

Design of PCR primers: As target for PCR primers the amelogenin gene was chosen in this study. Based on the information obtained from the alignment of AMELX gene (GenBank accession No. M63499.1), AMELY gene (GenBank accession No. M63500.1) sequences, a pair of primers AML-1F (GGCCAACA CTCCATGACTCCA), AML-1R (TGGGGAATAT YGGAGGCAGAG) was designed with homology between $\mathrm{X}$ and $\mathrm{Y}$ chromosome. The primers were expected to yield a PCR fragment of $241 \mathrm{bp}$ with the $A M E L X$ gene as target sequence and $178 \mathrm{bp}$ with $A M E L Y$ gene, respectively. (Figure-1). The PCR primers were synthesized by Eurofins Genomics India Pvt Ltd, Bangalore.

PCR amplification: Polymerase chain reaction (PCR) was performed in $25 \mu \mathrm{l}$ of reaction mixture containing $50 \mathrm{ng}$ of genomic DNA, $200 \mu \mathrm{m}$ of each dNTP, $1.5 \mathrm{mM} \mathrm{MgCl}$, 5 pmoles of each primer, 1 unit GoTaq $^{\circledR}$ Flexi DNA Polymerase (Promega, Madison, WI, USA), 1x PCR- colored buffer (Promega, Madison, WI, USA) and nuclease free water to make a final volume. Amplification was performed on a PTC200 DNA Engine ${ }^{\circledR}$ thermal cycler, (Bio-Rad, USA) using $0.2 \mathrm{ml}$ reaction tubes. The $\mathrm{PCR}$ programme consisted of $5 \mathrm{~min}$ denaturation at $94^{\circ} \mathrm{C}$, followed by 34 cycles of denaturation $\left(94^{\circ} \mathrm{C}, 45 \mathrm{sec}\right)$, annealing $\left(60^{\circ} \mathrm{C}, 45 \mathrm{sec}\right)$ and primer extension $\left(72^{\circ} \mathrm{C}, 60 \mathrm{sec}\right)$. The final cycle was followed by extension at $72^{\circ} \mathrm{C}$ for $10 \mathrm{~min}$ and indefinite hold time at $4^{\circ} \mathrm{C}$.

Gel electrophoresis: The PCR product obtained was analyzed by agarose gel electrophoresis in $2 \%$ agarose gels (AMRESCO Inc., USA) stained with ethidium bromide. A 100 bp DNA ladder (O'Gene Ruler, Fermentas) was electrophoresed simultaneously in order to assess the size of amplification product. The gels were visualized in automatic gel documentation system (MiniBis, DNR Bio-Imaging Systems) and the size of the amplicon was determined using software available with the gel documentation system.

\section{Results and Discussion}

PCR products of cattle meat samples after electrophoresis showed two bands $(241,178-b p)$ for tissue from male while female tissue resulted in only one (241-bp) band (Figure-2).

The objective of this study was to develop a cattle meat sexing assay based on the amelogenin gene 


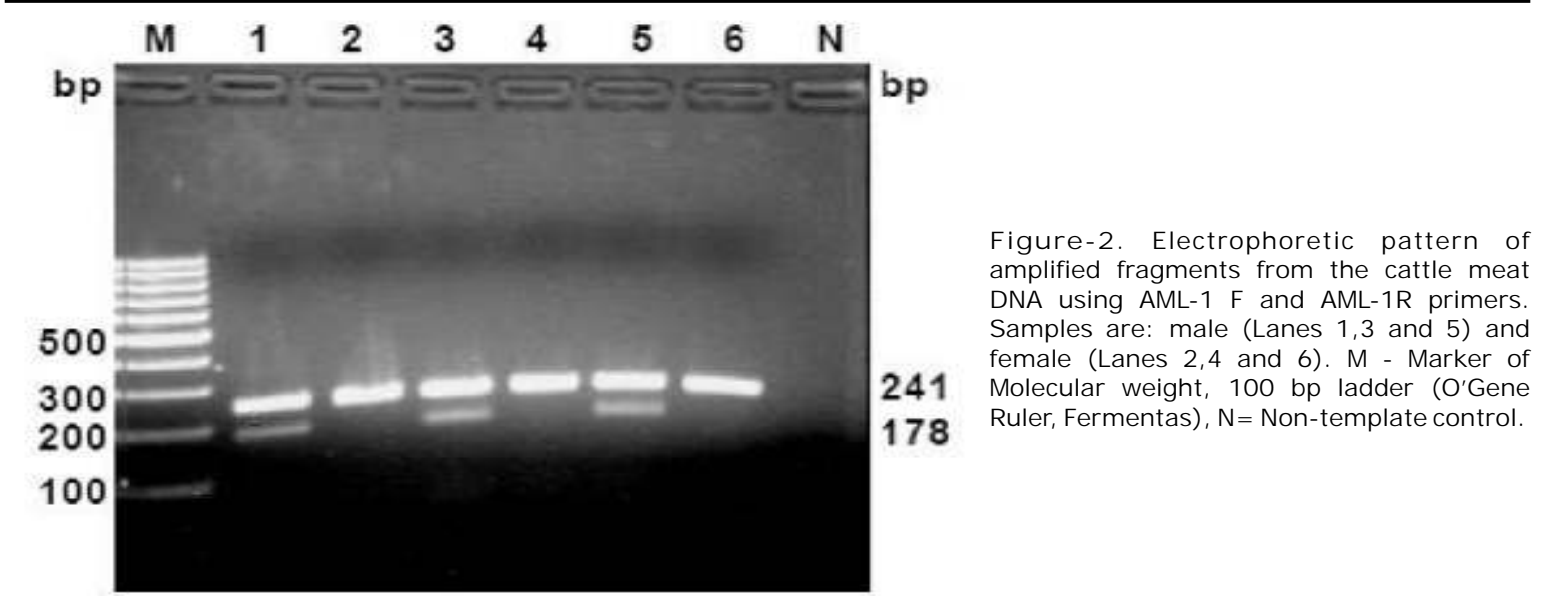

(AMELX/AMELY) using PCR technique which is superior to earlier work in terms of band patterns. The most common approach in sexing cattle meat involves the co amplification of the Y-chromosome specific sequence containing the Y-linked genes (SRY) and an autosomal sequence that acts as a control for the presence of DNA [21]. In the present study, we employed primers derived from a sequence for $\mathrm{X}$ and $\mathrm{Y}$ specific amelogenin, and verified the accuracy of the assay by evaluating genomic DNA from 8 males and 8 females. The overall amplification products obtained showed $100 \%$ accuracy. This assay provides a rapid and sensitive method for sexing, because of the presence of the X chromosome band. This result was superior to those reported by other authors [7,8]. Ennis and Gallagher [7] reported the primer pairs which yielded 280 and $217 \mathrm{bp}$, whereas the primer pairs, suggested by Chen et al [8] resulted in amplified product of 417 and $340 \mathrm{bp}$ in cattle. However we have attempted to explore the amelogenin gene for designing the primers, which could amplify the relative bands of smaller size and our self-designed primers effectively amplified the PCR products below $250 \mathrm{bp}$.

Amelogenin gene encodes for a protein found in developing tooth enamel which belongs to the family of extra cellular matrix proteins [22]. In most mammals the amelogenin gene is located on both $\mathrm{X}$ and $\mathrm{Y}$ chromosomes (AMELX and AMELY) [23], but a 63 bp deletion in exon 5 of the AMELY gene in comparison to the AMELX homologue yields two different size bands in male and two similar size bands (which appear as a single band on resolution) in female [22]. Due to an insertion in the region amplified in the $X$ specific gene (AMELX) or a deletion in the Y specific gene (AMELY), the amplified fragments are of different sizes. Due to length polymorphism between
AMELX and AMELY, this gene is used as a target for sex determination in mammals like humans [24], cattle [25], horses [26] and sheep or goats [27].

\section{Conclusions}

In conclusion our findings show that the PCR assay based on the amelogenin gene is reliable for sex determination in cattle meat. Due to the relatively short size $(<250-b p)$ of the products compared to earlier work, this method can be successfully applied to sex determination of cattle meat samples from highly degraded DNA and also in a shorter period of time. The PCR product comparatively shorter in size, size difference between band from AMELX and AMELY was more prominent on resolution, ensuring no ambiguity. Also, the advantage of this assay is that neither additional control amplicons with a second locus-specific autosomal primer pair nor restriction endonuclease steps are necessary for sex determination and control of the PCR reaction. The method proved to be reliable, cheap and is potentially suitable for routine analyses.

\section{Author's contribution}

P. Gokulakrishnan carried out the experiment and drafted the manuscript. R.R. Kumar, B.D. Sharma, S.K. Mendiratta guided during the research and helped in drafting of manuscript. D. Sharma provided the laboratory facilities and guided the study. O.P. Malav helped in collection of sample. All authors read and approved the final manuscript.

\section{Acknowledgements}

The authors gratefully acknowledge Indian Veterinary Research Institute (IVRI) and Central Avian Research Institute (CARI), Izatnagar, India for 
providing necessary facilities to accomplish this research.

\section{References}

1. Zeleny, R. and Schimmel, H. (2002). Sexing of beef- a survey of possible methods. Meat Science, 60: 69-75.

2. Simontacchi, C., Marinelli, L., Gabai, G., Bono, G. and Angeletti, R. (1999). Accuracy in naturally occurring anabolic steroid assays in cattle and first approach to quality control in Italy. Analyst, 124:307-312.

3. Draisci, R., Palleschi, L., Ferretti, E., Lucentini, L. and Cammarata, P. (2000). Quantitation of anabolic hormones and their metabolites in serum and urine by liquid chromatography-tandem mass spectrometry. Journal of Chromatography A, 870: 511-522.

4. Hartwig, M., Hartmann, S. and Steinhart, H. (1997). Physiological quantities of naturally occurring steroid hormones (androgens and progestogens), precursors and metabolites in beef of differing sexual origin. $Z$. Lebensm. Unters. Forsch. A., 205: 5-10.

5. Tagliavini, J., Bolchi, A., Bracchi, P.G. and Ottonello, S. (1993). Sex determination on samples of bovine meat by polymerase chain reaction. Journal of Food Science, 58: 237-238, 244.

6. Appa Rao, K.B.C., Kesava Rao, V., Kowale, B.N. and Totey, S.M. (1995). Sex specific identification of raw meat from cattle, buffalo, sheep and goat. Meat Science, 39: 123-126.

7. Ennis, S. and Gallagher, T.F. (1994). APCR-based sex determination assay in cattle based on the bovine amelogenin locus. Animal Genetics, 25: 425-427.

8. Chen, C.M., Hu, C.L., Wang, C.H., Hung, C.M., Wu, H.K. and Choo, K.B. (1999). Gender determination in single bovine blastomeres by polymerase chain reaction amplification of sex-specific polymorphic fragments in the amelogenin gene. Molecular Reproduction and Development, 54(3): 209-214.

9. Fontanesi, L., Scotti, E. and Russo, V. (2008). Differences of the porcine amelogenin $\mathrm{X}$ and $\mathrm{Y}$ chromosome genes (AMELX and AMELY) and their application for sex determination in pigs. Molecular Reproduction and Development, 75: 1662-1668.

10. Aasen, E. and Medrano, J.F. (1990). Amplification of the $Z F Y$ and $Z F X$ genes for sex identification in humans, cattle, sheep and goats. Bio/Technology, 8: 1279-1281.

11. Kirkpatrick, B.W. and Monson, R.L. (1993).Sensitive sex determination assay applicable to bovine embryos derived from IVM and IVF. Journal of Reproduction and Fertility, 98: 335-340.

12. Zinovieva, N., Palma, G., Muller, M. and Brem, G. (1995). A rapid sex determination test for bovine blastomeres using allele specific PCR primers and capillary PCR. Theriogenology, 43: 365.

13. Lockley, A.K., Bruce, J.S., Franklin, S.J. and Bardsley, R.G. (1997). Simultaneous detection of a sex-speci? c sequence and the Ryr1 point mutation in porcine genomic DNA, Meat Sci., 45: 485-490.

14. Lu, W., Rawlings, N., Zhao, J. and Wang, H. (2007).
Amplification and application of the HMG box of bovine SRY gene for sex determination. Animal Reproduction Science, 100: 186-191.

15. Fu, Q., Zhang, M., Qin, W.S., Lu, Y.Q., Zheng, H.Y. and Meng, B. (2007). Cloning the swamp buffalo $S R Y$ gene for embryo sexing with multiplex-nested PCR. Theriogenology, 68: 1211-1218.

16. Shi, L., Yue, W., Ren, Y., Lei, F. and Zhao, J. (2008). Sex determination in goat by amplification of the HMG box using duplex PCR. Animal Reproduction Science, 105: 398-403.

17. Matthews, M.E. and Reed, K.C. (1992). Sequences from a family of bovine $\mathrm{Y}$ chromosomal repeats, Genomics, 13: 1267-1273.

18. Miller, J.R. and Koopman, M. (1990). Isolation and characterization of two male-specific DNA fragments from the bovine gene. Animal Genetics, 21:77-82.

19. Ballin, N.Z. and Madsen, K.G. (2007). Sex determination in beef by melting curve analysis of PCR amplicons from the amelogenin locus. Meat Science, 77(3): 384-388.

20. Parati, K., Bongioni, G., Aleandri, R. and Galli, A. (2006). Sex ratio determination in bovine semen: A new approach by quantitative real time PCR. Theriogenology, 66(9): 2202-2209.

21. Mara, L., Pilichi, S., Sanna, A., Accardo, C., Chessa, B., Chessa, F., Dattena, M., Bomboi, G. and Cappai, P. (2004). Sexing of in vitro produced ovine embryos by duplex PCR. Molecular Reproduction and Development, 69:35-42.

22. Gibson, C.W. (1999). Regulation of amelogenin gene expression. Critical Reviews in Eukaryotic Gene Expression, 9: 45-57.

23. Iwase, M., Satta, Y., Hirai, Y., Hirai, H., Imai, H. and Takahata, N. (2003). The amelogenin loci span an ancient pseudo autosomal boundary in diverse mammalian species. Proceedings of the National Academy of Sciences, USA, 100: 5258-5263.

24. Gibbon, V., Paximadis, M., Strkalj, G., Ruff, P. and Penny, C. (2009). Novel methods of molecular sex identification from skeletal tissue using the amelogenin gene. Forensic Science International: Genetics, 3: 74-79.

25. Weikard, R., Pitra, C. and Kuhn, C. (2006). Amelogenin cross-amplification in the family Bovidae and its application for sex determination. Molecular Reproduction and Development, 73: 1333-1337.

26. Hasegawa, T., Sato, F., Ishida, N., Fukushima, Y. and Mukoyama, H. (2000). Sex determination by simultaneous amplification of equine SRY and amelogenin genes. The Journal of Veterinary Medical Science, 62: 1109-1110.

27. Pfeiffer, I. and Brenig, B. (2005). X and Y chromosome specific variants of the amelogenin gene allow sex determination in sheep (Ovis aries) and European red deer (Cervus elaphus). BMC Genetics, 6: 16.

$* * * * * * * *$ 